\title{
Penurunan Nyeri Dismenorea Primer melalui Kompres Hangat pada Remaja
}

\author{
Murtiningsih, Lina Karlina \\ STIKes Ahmad yani \\ Email:murty_68@yahoo.com
}

\begin{abstract}
Abstrak
Angka kejadian dismenorea primer pada remaja wanita usia 14-19 tahun di Indonesia sekitar 54, 89 \%. Di SMA Negeri I Cimahi pada tahun 2014, jumlah siswi kelas XI 167 orang, sebanyak 161 orang (96,4\%) siswi mengalami dismenorea. Dampak dismenorea berat menyebabkan $(27,7 \%)$ siswi tidak dapat mengikuti proses pembelajaran, tidak masuk sekolah, dan mengganggu aktivitas sehari-hari. Beratnya dismenorea dibutuhkan penanganan non farmakologi yang cukup terjangkau, hemat dan efisien, salah satunya menggunakan kompres hangat. Penelitian ini bertujuan untuk mengetahui pengaruh kompres hangat terhadap dismenorea primer pada remaja. Metode penelitian yang digunakan adalah quasy experiment dengan pendekatan one group pretest-posttest design. Populasi penelitian remaja kelas XI SMA Negeri 1 Cimahi tahun 2014 yang mengalami dismenorea sebanyak 83 orang. Sebanyak 18 responden diambil sebagai sampel melalui teknik simple random sampling. Untuk mengukur skala nyeri digunakan Verbal Descriptor Scale (VDS), tingkat nyeri diukur sebelum dan setelah kompres hangat dengan suhu air $46^{\circ} \mathrm{C}$ selama 20 menit. Data analisis dengan uji Wilcoxon. Hasil penelitian menunjukkan rata-rata tingkat nyeri dismenorea sebelum kompres 6.5 dengan standar deviasi 1.654 dan setelah kompres hangat 4.22 dengan standar deviasi 1.665. Hasil uji statistik menunjukkan terdapat perbedaan pada tingkat sebelum dan sesudah kompres hangat pada remaja. Disarankan bagi pihak puskesmas dan sekolah untuk meningkatkan frekuensi penyuluhan tentang penanganan nyeri dismenorea pada remaja dengan metode non farmakologi yang murah, mudah, efektif dan efisien menggunakan kompres hangat dan agar sekolah memfasilitasi peralatan untuk kompres hangat.
\end{abstract}

Kata kunci: Dismenorea, kompres, nyeri, remaja, skala.

\section{Effect of Warm Compress on Decreasing Primary Dysmenorrhea Pain in Adolescents}

\begin{abstract}
In Indonesia, primary dysmenorrhea occurs in 54.89\% of adolescent girls age 14-19 years old. At SMA Negeri 1 Cimahi (Cimahi 1 High School) in 2014, 161 in 167 (96.4\%) second-grade female students had dysmenorrhea. Severe dysmenorrhea interrupted daily activities of $27.7 \%$ of students and caused them to be distracted in class and miss school. Severe dysmenorrhea requires affordable, cheaper and efficient nonpharmacological treatment, such as warm compress. The research aimed to identify the effect of warm compress in adolescents with primary dysmenorrhea. The study used Quasy experiment method with one group pretest-posttest design. Out of 83 secondgrade female students at SMA Negeri I Cimahi Year 2014, 18 respondents were selected using simple random technique sampling. Pain score was measured using Verbal Descriptor Scale (VDS) before and after students were given warm compress for 20 minutes with water temperature of $46^{\circ} \mathrm{C}$. The statistical analysis used Wilcoxon formula. The results showed that the pain level before given warm compress was 6.5 with deviation standard of 1.654, and after given warm compress was 4.22 with deviation standard of 1.665 . The statistical analysis showed that warm compress affected dysmenorrhea with a p-value of $0.000(<\alpha=0.05)$. It was concluded that warm compress is able to influence dysmenorrhea pain level in adolescents. It was suggested to the community health center and to the school that they should conduct more health educations sessions about management of dysmenorrhea in adolescents, particularly about nonpharmacological technique of warm compress which is cheap, easy, effective and efficient. The school health clinic was also suggested to start providing warm compress.
\end{abstract}

Key words: Adolescent, compress, dysmenorrhea, pain, scale. 
Murtiningsih: Penurunan Nyeri Dismenore Primer melalui Kompres Hangat

\section{Pendahuluan}

Dismenorea merupakan nyeri selama atau segera sebelum menstruasi menjadi salah satu masalah ginekologikyang palingumum terjadi pada wanita dari segala usia (Lowdermilk, 2010). Dismenorea primer terjadi pada 6-12 bulan setelah menarche, disebabkan tingginya kadar prostaglandin (PGs) yang direlease dari secretory endometrium sehingga menimbulkan kontraksi uterus yang menyakitkan. Dismenorea sekunder merupakan nyeri menstruasi yang disebabkan oleh patologi pada pelvik atau uterus, dapat terjadi setiap waktu setelah menarche (Bajrai, et al., 2010). Hasil penelitian Pusat Informasi dan Konseling Kesehatan Reproduksi Remaja (PIK-KRR) di Indonesia tahun 2009 angka kejadian dismenorea primer $72,89 \%$ dan dismenorea sekunder $27,11 \%$. Angka kejadian dismenorea sekitar $45-95 \%$ dikalangan wanita usia produktif (Proverawati \& Misaroh, 2009).

Prevalensi dismenorea di Indonesia tahun 2008 sebesar $64,25 \%$ yang terdiri dari $54,89 \%$ dismenorea primer dan 9,36\% dismenorea sekunder (Proverawati \& Misaroh, 2009). Hasil penelitian Mahmudiono pada tahun 2011, angka kejadian dismenorea primer pada remaja wanita usia 14-19 tahun di Indonesia sekitar 54, $89 \%$.

Dismenorea sangat berdampak pada remaja usia sekolah karena menyebabkan terganggunya aktivitas sehari-hari. Jika seorang siswi mengalami dismenorea, aktivitas belajar mereka di sekolah terganggu dan tak jarang hal ini membuat mereka tidak masuk sekolah. Selain itu kualitas hidup remaja menurun. Seorang siswi yang mengalami dismenorea tidak dapat berkonsentrasi belajar dan motivasi belajar akan menurun karena dismenorea yang dirasakan pada saat proses belajar mengajar (Ningsih, 2011). Dismenorea pada remaja harus dapat ditangani dengan tindakan yang tepat untuk menghindari dampak negatif yang akan timbul.

Dismenorea dapat dikurangi secara farmakologis dan non farmakologis. Secara nonfarmakologis diantaranya istirahat yang cukup, mengonsumsi minuman hangat berkalsium tinggi, relaksasi dalam atau yoga, melakukan aktivitas fisik seperti olah raga, bersepeda dan senam aerobik, akupresure, mandi dengan air hangat, kompres dengan kantong air panas (buli-buli) / hangat pada bagian yang terasa nyeri (Kozier \& Erb's, 2009 \& Bobak, 2005). Kompres hangat dengan buli-buli panas menyebabkan konduksi, dimana terjadi pemindahan panas dari buli-buli ke dalam tubuh sehingga terjadi pelebaran pembuluh darah dan penurunan ketegangan otot sehingga nyeri dismenorea yang dirasakan akan berkurang atau hilang (Potter \& Perry, 2006). Berdasarkan dari hasil penelitian sebelumnya pada 30 responden di STIKES RS Baptis Kediri, didapatkan 16 responden $(53,3 \%)$ mengalami nyeri berat dan 14 responden $(46,7 \%)$ mengalami nyeri sedang sebelum diberikan kompres hangat, sesudah kompres hangat 19 responden $(63,3 \%)$ mengalami intensitas nyeri ringan dan 11 responden $(36,7 \%)$ nyeri sedang (Wahyuningsih, 2013).

Masih banyak remaja di SMA Negeri 1 Cimahi yang menangani dismenorea dengan mengonsumsi obat, minuman kunyit, minum air hangat dan sebagian dari mereka tidak pernah menggunakan apapun untuk mengurangi dismenorea. Salah satu penanganan dismenorea dengan nonfarmakologis yaitu kompres hangat. Kompres hangat dilakukan dengan menggunakan buli-buli berisi air panas $46^{\circ} \mathrm{C}$ yang dibungkus kain akan mengoptimalkan proses konduksi, dimana terjadi pemindahan panas dari buli-buli ke dalam tubuh sehingga akan menyebabkan pelebaran pembuluh darah dan akan terjadi penurunan ketegangan otot sehingga nyeri dismenorea yang dirasakan akan berkurang atau hilang. Kompres hangat mudah dilakukan, ekonomis, terjangkau dan lebih efektif.

SMA Negeri 1 Cimahi merupakan SMA dengan siswi yang mengalami dismenorea cukup banyak. Responden pada penelitian ini siswi kelas XI, dimana siswinya sudah beradaptasi lebih lama daripada siswi baru kelas X, dan bukan siswi kelas XII yang sedang persiapan UN karena dikawatirkan mengalami stres yang dapat memengaruhi nyeri dismenorea. Berdasarkan hasil pengambilan data tanggal 25 Januari 2014 pada 167 siswi kelas XI didapatkan siswi yang mengalami dismenorea 161 orang $(96,41 \%)$, dengan klasifikasi dismenorea ringan 78 
Murtiningsih: Penurunan Nyeri Dismenore Primer melalui Kompres Hangat

orang $(48,4 \%)$, dismenorea sedang 65 orang $(40,4 \%)$, dismenorea berat terkontrol 14 orang $(8,7 \%)$ dan dismenorea berat tidak terkontrol 4 orang $(2,48 \%)$. Dampak dari dismenorea tersebut menyebabkan $(27,7 \%)$ dari mereka tidak dapat mengikuti proses pembelajaran dan tak jarang mereka meminta ijin untuk tidak masuk sekolah, sehingga dampak tersebut dapat mengganggu kegiatan seharihari. Hasil wawancara pada sebagian siswi yang mengalami dismenorea didapatkan bahwa mereka melakukan cara untuk mengurangi nyeri dengan mengonsumsi obat, minuman kunyit, minum air hangat dan tidur. Apabila dismenorea terjadi di sekolah mereka istirahat di ruang UKS atau minum obat sesuai kebiasaan masing-masing siswi. Menurut mereka yang mengalami dismenorea berat, nyeri tidak teratasi hanya dengan mengonsumsi kunyit. Berdasarkan fenomena tersebut, maka tujuan penelitian ini adalah untuk mengetahui pengaruh kompres hangat terhadap dismenorea primer pada remaja kelas XI SMA Negeri 1 Cimahi.

\section{Metode Penelitian}

Rancangan penelitian ini menggunakan quasi eksperimen tanpa ada kelompok kontrol, yaitu One Group PreTest - Post test design (Grove, Burns \& Gray, 2013). Penelitian dilakukan dengan cara memberikan pretest sebelum intervensi dan posttest setelah intervensi. Penelitian ini bertujuan untuk mengetahui pengaruh kompres hangat dalam mengurangi skala nyeri dismenorea primer pada siswi kelas XI di SMA Negeri 1 Cimahi.

Variabel independen pada penelitian ini adalah kompres hangat. Variabel dependennya adalah nyeri saat menstruasi sebelum dilakukan kompres hangat dan nyeri menstruasi setelah dilakukan kompres hangat. Populasi penelitian adalah siswi kelas 2 SMA Negeri 1 Cimahi yang berjumlah 83 orang, jumlah sampel ditentukan berdasarkan rumus Dahlan (2012), didapatkan sampel sejumlah 18 orang siswi yang mengalami dismenorea. Sampel diambil dengan teknik Simple Random Sampling dengan cara mengundi anggota populasi.

Adapun kriteria inklusi yang ditetapkan sebagai berikut; remaja putri mengalami dismenorea sedang dan berat, terjadi pada saat 24 jam saat menstruasi tiba, tidak menderita dismenorea yang tidak terkontrol, tidak sedang dalam pengobatan, dan siklus menstruasi regular setiap bulan. Setelah diberikan informed consent pada 18 responden, peneliti memberitahukan agar pada saat penelitian responden tidak mengonsumsi obat-obatan. Pada saat responden mengalami dismenorea hari pertama, responden memberitahukan kepada peneliti dengan cara mengirim pesan melalui telepon atau telepon langsung. Kemudian peneliti datang ke sekolah responden untuk memberikan intervensi kompres hangat di ruang UKS. Intervensi diberikan secara perorangan dan dilakukan sesuai waktu dan tempat yang telah disepakati.

Sebelum diberikan intervensi, responden dipersilahkan untuk mengisi kuesioner skala nyeri, kemudian dilakukan kompres hangat menggunakan buli-buli karet dibungkus kantong kain bersih dengan ukuran $26 \mathrm{~cm}$ x $18 \mathrm{~cm}$, diisi air panas $500 \mathrm{ml}$ dengan suhu air $46^{\circ} \mathrm{C}$ diukur menggunakan termometer air, diletakkan di area abdomen bawah selama 20 menit, dengan posisi responden semi fowler. Setelah diberikan intervensi kemudian peneliti langsung membereskan peralatan selama 2 menit dan peneliti memberikan kembali kuesioner skala nyeri untuk diisi kembali oleh responden. Instrumen penelitian yang digunakan adalah lembar check list intensitas nyeri yaitu skala pendeskripsi verbal (Verbal Descriptor Scale/VDS); merupakan sebuah garis terdiri angka 0 sampai 10, "0 merupakan tidak nyeri", " $1-3$ nyeri ringan", "4-6 nyeri sedang ", "7-9 nyeri berat terkontrol" dan "10 nyeri berat tidak terkontrol".

Analisis data dilakukan peneliti untuk menjawab tujuan yang ingin dicapai dalam penelitian ini, yaitu analisis univariat dan bivariat. Analisis univariat untuk mengetahui rata-rata skala nyeri dismenorea sebelum kompres hangat, dan rata-rata skala nyeri dismenorea setelah kompres hangat. Analisis bivariat dilakukanuntukmengetahuipengaruh kompres hangat terhadap dismenorea primer pada remaja, analisis yang digunakan uji nonparametrik dengan menggunakan uji Wilcoxon.

Etika penelitian dilakukan dangan cara 
Murtiningsih: Penurunan Nyeri Dismenore Primer melalui Kompres Hangat

peneliti memberikan penjelasan kepada responden tentang maksud dan tujuan penelitian, apabila setuju responden menandatangani informed consent, kemudian dilakukan pengukuran skala nyeri dismenorea dan intervensi pemberian kompres hangat. Responden mempunyai hak otonomi untuk berpartisapasi dalam penelitian ini atau tidak. Peneliti membebaskan responden yang tidak siap dijadikan subjek penelitian untuk mengundurkan diri kapanpun tanpa adanya dampak pada responden. Untuk menjaga privacy intervensi dilakukan ditempat tertutup yaitu di ruang UKS dengan fasilitas tempat tidur, selimut dan sampiran.

Penelitian ini dilakukan dengan memerhatikan kenyamanan responden dan tidak melakukan tindakan yang membahayakan responden. Selain itu peneliti meminimalisir risiko dari tindakan yang diberikan dengan memerhatikan kondisi kulit responden sebelum diberikan terapi seperti kemerahan, bengkak, adanya luka dan adanya alergi terhadap buli-buli air panas untuk menghindari cedera. Penelitian ini tidak akan membahayakan responden karena tindakan ini merupakan tindakan non farmakologi dan tidak ada efek samping. Kenyamanan responden baik fisik, emosi dan lingkungan tetap dipertahankan.

Peneliti juga tidak membeda-bedakan perlakuan terhadap responden. Responden diperlakukan sama dengan responden yang lain sesuai dengan standar operasional prosedur (SOP). Peneliti menjaga kerahasiaan responden dengan tidak mencantumkan namanya (anonymity) pada lembar pengumpulan data. Kerahasian informasi responden akan dijamin oleh peneliti, hanya data yang diperlukan saja yang akan disajikan atau dilaporkan sebagai hasil penelitian.

\section{Hasil Penelitian}

Hasil dari pengolahan data ini disajikan dalam bentuk tabel yang terdiri dari hasil analisis univariat untuk mengetahui rata-rata nyeri dismenorea sebelum dan setelah diberikan kompres hangat dan analisis bivariat untuk mengetahui adanya pengaruh dari variabel independen terhadap variabel dependen.

1. Rata-rata dismenorea sebelum diberikan kompres hangat

Tabel 1 Distribusi rata-rata dismenorea primer sebelum dilakukan kompres hangat pada remaja kelas XI SMA Negeri 1 Cimahi Tahun 2014

Tabel 1 memperlihatkan bahwa nilai ratarata nyeri dismenorea sebelum dilakukan kompres hangat adalah 6.50. Pada pre-test diketahui hasil skor terendah adalah 4 dan hasil skor tertinggi adalah 9 dengan standard deviation 1.654 dan median 7.00 .

2. Rata-rata Nyeri Dismenorea Setelah Dilakukan Kompres Hangat

Tabel 2 Distribusi rata-rata dismenorea primer setelah dilakukan kompres hangat pada remaja pada remaja kelas XI SMA Negeri 1 Cimahi Tahun 2014

Tabel 2 tersebut memperlihatkan nilai rata-rata tingkat nyeri dismenorea sesudah

Tabel 1 Distribusi Rata-Rata Dismenorea Primer Sebelum dilakukan Kompres Hangat pada Remaja Kelas XI SMA Negeri 1 Cimahi Tahun 2014

\begin{tabular}{cccccc}
\hline Variabel & Pengukuran & Mean & SD & (Median) & 95\% \\
\cline { 5 - 5 } & & & & Minimal -maksimal & CI \\
\hline \multirow{2}{*}{ Nyeri } & Pre test & 6.5 & 1.654 & $(7.00)$ & $5.68-7.32$ \\
& & & & $4-9$ & \\
\hline
\end{tabular}

Tabel 2 Distribusi Rata-Rata Dismenorea Primer Setelah dilakukan Kompres Hangat pada Remaja Kelas XI SMA Negeri 1 Cimahi Tahun 2014

\begin{tabular}{cccccc}
\hline Variabel & Pengukuran & Mean & SD & (Median) & $\mathbf{9 5 \%}$ \\
\cline { 4 - 6 } & & & $\begin{array}{c}\text { Minimal - } \\
\text { maksimal }\end{array}$ & CI \\
\hline Nyeri & Post test & 4.22 & 1.665 & $(4.50)$ & $3.39-5.05$ \\
\hline
\end{tabular}


Murtiningsih: Penurunan Nyeri Dismenore Primer melalui Kompres Hangat

Tabel 3 Pengaruh Kompres Hangat terhadap Dismenorea Primer pada Remaja Kelas XI SMA Negeri 1 Cimahi Tahun 2014

\begin{tabular}{cccccc}
\hline Variabel & Pengukuran & $\mathbf{N}$ & (Median) & $\begin{array}{c}\text { Rata-Rata } \pm \\
\text { SD }\end{array}$ & $\boldsymbol{P}$ \\
\cline { 3 - 6 } & & & Minimal -maksimal & & Value \\
\hline \multirow{2}{*}{ Nyeri } & Pre test & 18 & $7.00(4-9)$ & $6.50 \pm 1.654$ & \\
& Post test & 18 & $4.50(1-7)$ & $4.22 \pm 1.665$ & 0.000 \\
\hline
\end{tabular}

dilakukan kompres hangat 4.22. Pada posttest diketahui hasil skor terendah adalah 1 dan hasil skor tertinggi adalah 7 dengan standard deviation 1.665 dan median 4.50 .

\section{Pengaruh Kompres Hangat Terhadap Dismenorea Primer \\ Tabel 3 Pengaruh kompres hangat terhadap dismenorea primer pada remaja kelas XI SMA Negeri 1 Cimahi Tahun 2014 \\ Tabel 3 tersebut memperlihatkan bahwa hasil uji Wilcoxon didapatkan p-value 0.000 $(<\alpha=0.05)$ maka H0 ditolak dan Ha diterima. Hal ini dapat disimpulkan bahwa kompres hangat berpengaruh dalam menurunkan tingkat nyeri dismenorea primer pada remaja kelas XI SMA Negeri 1 Cimahi tahun 2014.}

\section{Pembahasan}

1. Rata-rata dismenorea sebelum dilakukan kompres hangat

Berdasarkan hasil penelitian didapatkan data bahwa nyeri dismenorea sebelum dilakukan kompres hangat nilai terendah adalah 4 , nilai tertinggi adalah 9 dan nilai yang sering muncul adalah 8 . Hasil tersebut sesuai dengan penelitian Oktaviana (2012) di Asrama Kebidanan Tanjungkarang tahun 2012 didapatkan data bahwa rata-rata nyeri dismenorea sebelum dilakukan kompres hangat didapatkan nilai terendah adalah 3 (ringan), nilai tertinggi adalah 8 dan nilai yang sering muncul adalah 6 hasil dari skala $1-10$.

Sesuai data yang didapatkan dari responden rata-rata responden yang mengalami nyeri (skala 7-9) yang dideskriptifkan dismenorea berat hampir seluruhnya meninggalkan proses pembelajaran karena tidak kuat menahan nyeri, pusing, lemas yang mengharuskan mereka untuk berbaring di UKS. Data tersebut menunjukkan responden yang mengalami nyeri (dari skala 4-9) yang dideskriptifkan dismenorea sedang sampai berat seluruhnya mengatakan ketika mereka sedang mengalami dismenorea mereka tidak mengonsumsi obat atau menggunakan hal yang lainnya untuk mengurangi nyeri. Alasan mereka tidak menggunakan obat-obatan karena mereka takut menimbulkan dampak ketergantungan terhadap obat-obatan. Sesuai yang disampaikan oleh Kozier \& Erb's, (2009), bahwa penanganan secara farmakologi yaitu penggunaan obat-obatan akan menyebabkan ketergantungan dan memiliki kontraindikasi yaitu hipersensitivitas, ulkus peptik (tukak lambung), perdarahan atau perforasi gastrointestinal, insufisiensi ginjal, dan risiko tinggi perdarahan. Adapun penanganan dismenorea secara non farmakologi yaitu dengan kompres hangat, dinyatakan cukup efektif, hemat dan terjangkau serta tidak akan menimbulkan efek samping.

Hasil penelitian ini menunjukkan tingkat nyeri dismenorea responden bervariasi karena nyeri yang dirasakan individu satu dengan yang lainnya tidak sama, dari tingkat dismenorea sedang sampai berat. Sesuai yang disampaikan (Tamsuri, 2007), bahwa perbedaan nyeri ini dipengaruhi oleh beberapa faktor seperti usia, jenis kelamin, kultur/budaya, dukungan keluarga/sosial, dan koping. Kondisi tubuh seseorang yang tidak akan sama satu dengan yang lainnya yang disebabkan oleh perbedaan kadar endorphin. Endorphin berfungsi mengatur berbagai fungsi fisiologi transmisi nyeri, emosi, kontrol nafsu makan dan sekresi hormon. Perbedaan kadar endorphin yang tinggi akan sedikit merasakan nyeri dan kadar endorphin yang sedikit akan merasakan nyeri yang berlebih (Harry, 2007). 
Murtiningsih: Penurunan Nyeri Dismenore Primer melalui Kompres Hangat

Sesuai yang disampaikan oleh (Proverawati \& Misaroh, 2009), bahwa setiap remaja mempunyai pengalaman nyeri dismenorea yang berbeda-beda, dimana hal itu muncul rasa tidak nyaman, letih dan sakit yang dapat mengganggu aktivitas seharihari. Setiap menstruasi menyebabkan rasa nyeri terutama pada awal menstruasi, namun dengan kadar nyeri berbeda-beda dengan tingkat keparahan, yaitu ringan, sedang dan berat.

Usia remaja banyak yang mengalami dismenorea yaitu sekitar $60-80 \%$ karena mereka sedang mengalami tahap pertumbuhan dan perkembangan fisik. Menurut (Harry, 2007), dismenorea dapat berlebihan jika dipengaruhi oleh faktor psikis dan fisik seperti stres, syok, kurang darah, dan kondisi tubuh yang menurun.

Hal ini sesuai dengan penelitian yang dilakukan Sophia (2013) didapatkan bahwa berdasarkan kelompok umur, responden tertinggi yang mengalami dismenorea terdapat pada kelompok umur 15 - 17 tahun $(83,00 \%)$ dan yang terendah adalah pada kelompok umur $\leq 14$ tahun $(8,20 \%)$. Hal ini dapat terjadi karena pada umumnya siswi SMA yang berada pada usia 14-18 tahun karena pada usia remaja terjadi perkembangan organ-organ reproduksi dan perubahan hormonal yang signifikan. Hal yang paling utama yang menyebabkan dismenorea primer adalah adanya hubungan hormon estrogen, progesteron, dan prostaglandin F2 $\alpha$ yang menyebabkan kontraksi otot-otot polos. Jika jumlah prostaglandin F2 $\alpha$ berlebih akan dilepaskan dalam peredaran darah, maka selain dismenorea, dijumpai pula efek umum seperti diare, mual, dan muntah (Guyton \& Hall, 2007).

Penelitian ini dapat menjelaskan bahwa dismenorea pada remaja terjadi karena remaja mempunyai ambang nyeri yang rendah, sehingga sedikit rasa nyeri mereka dapat merasakan kesakitan, remaja yang mudah mengalami stres, contohnya dalam pelajaran atau saat menghadapi ulangan. Meskipun dismenorea bukan masalah fisik dan psikis, namun dismenorea dengan tingkatan nyerinya sering menimbulkan bahaya. Kondisi seperti ini membawa remaja pada situasi yang tidak menyenangkan. Melihat dampak dari dismenorea tersebut dapat dikatakan bahwa dismenorea merupakan salah satu problema dalam kehidupan remaja, yang memaksa mereka untuk menggunakan berbagai cara untuk mencegah terjadinya nyeri dismenorea. 2. Rata-rata nyeri dismenorea sesudah dilakukan kompres hangat

Berdasarkan hasil penelitian sesudah diberikan kompres hangat didapatkan paling banyak responden dengan nyeri (skala 1-3) yang dideskriptifkan dismenorea ringan. Dapat diartikan bahwa kompres hangat dapat menurunkan nyeri dismenorea, responden sebagian besar mengalami penurunan 2 skala nyeri. Penurunan nyeri responden ini karena kompres hangat dapat memberikan rasa hangat kepada responden untuk mengurangi nyeri, penurunan nyeri terjadi karena adanya perpindahan panas secara konduksi dari bulibuli yang diletakkan di perut bagian bawah ke dalam perut yang melancarkan peredaran darah, menurunkan ketegangan otot dan membuat nyaman/rileks pada responden.

Hasil tersebut didukung oleh penelitian Oktaviana (2012) di Asrama Kebidanan Tanjungkarang tahun 2012 bahwa rata-rata nyeri dismenorea sesudah dilakukan kompres hangat dari skala 1-10 terdapat nilai terendah adalah skala nyeri 2 (ringan) dan tertinggi adalah skala nyeri 6 (sedang) dan nilai yang sering muncul adalah skala nyeri 5 yaitu tingkat nyeri dismenorea sedang. Data yang didapatkan dari 5 orang $(27,7 \%)$ responden yang mengalami dismenorea berat (skala 7-9) dengan karakteristik secara objektif tidak dapat mengikuti perintah, meringis kesakitan, berbaring sambil membungkuk. Setelah diberikan kompres hangat mereka dapat mendeskripsikan nyerinya berkurang dan merasa nyaman kemudian mereka langsung kembali ke kelas untuk melanjutkan proses pembelajaran. Intervensi kompres hangat yang diberikan ini mampu mengurangi nyeri responden menjadi nyeri ringan (skala 1-3) sampai sedang sehingga mereka dapat melanjutkan aktivitas sehari-hari.

Fakta dilapangan dari 18 responden yang mengalami dismenorea dengan skala nyeri 4-6 dan 7-9 setelah dilakukan kompres hangat seluruh responden mengatakan ada penurunan nyeri. Dari yang mengalami dismenorea 7-9 menjadi 4-6 dan dari 4-6 
Murtiningsih: Penurunan Nyeri Dismenore Primer melalui Kompres Hangat

menjadi 1-3. Pemberian kompres hangat dilakukan dengan perlakuan yang sama dan sesuai prosedur dengan menggunakan bulibuli dan air panas, perpindahan panas akibat paparan langsung dari buli-buli ke perut bagian bawah.

Sesuai yang disampaikan oleh (Kozier \& Erb's, 2009), bahwa penggunaan kompres hangat membuat sirkulasi dan vaskularisasi darah lancar, dengan cara menggunakan bulibuli panas yang di bungkus dengan kantong. Cara pemindahannya secara konduksi dimana terjadi pemindahan panas dari bulibuli ke dalam perut bagian bawah sehingga terjadi vasodilatasi yang membuat relaksasi pada otot. Kompres panas dengan suhu $46^{\circ} \mathrm{C}$ mengakibatkan terjadinya vasodilatasi di daerah simphisis pubis yang bisa membuka aliran darah membuat sirkulasi darah lancar kembali sehingga terjadi relaksasi pada otot mengakibatkan kontraksi otot menurun dan nyeri berkurang.

3. Pengaruh kompres hangat terhadap nyeri dismenorea primer pada remaja kelas XI SMA Negeri 1 Cimahi tahun 2014

Hasil penelitian menunjukkan terdapat penurunan tingkat nyeri dismenorea sebelum dan sesudah diberikan kompres hangat. Hal ini menunjukkan ada pengaruh yang signifikan dari kompres hangat dalam menurunkan nyeri dismenorea pada remaja kelas XI SMA Negeri 1 Cimahi tahun 2014. Hasil penelitian ini juga didukung oleh hasil penelitian sebelumnya Wahyuningsih (2012) di STIKES R.S. Baptis Kediri Sesudah dilakukan uji statistik dengan uji Wilcoxon Signed Ranks Test didapatkan hasil intensitas nyeri sebelum dan sesudah dilakukan kompres hangat $\rho=0,00$. Karena $\alpha<0,05$ maka Ha diterima dan $\mathrm{H} 0$ ditolak, hal ini menunjukkan ada pengaruh yang signifikan sebelum dan sesudah dilakukan kompres hangat.

Penelitian ini senada dengan penelitian yang telah dilakukan oleh Ayu (2010) diperoleh penurunan rata-rata nyeri kelompok kompres hangat sebesar 2 derajat skala VAS dengan nilai $\mathrm{p}$ value $0,001(<0,005)$. Karena $\mathrm{P}$ value $<0,05$ sehingga $\mathrm{H} 0$ ditolak hal ini menunjukkan ada pengaruh yang signifikan sebelum dan sesudah dilakukan kompres hangat. Sesuai yang disampaikan oleh (Barbara, 2003 \& Kozier \& Erb's, 2009), bahwa panas juga meningkatkan pengiriman nutrisi dan kebutuhan oksigen ke daerah yang diberikan kompres dan kongesti vena menurun, meningkatkan suplai darah ke areaarea tubuh, penggunaan kompres air hangat dapat membuat sirkulasi darah lancar, dan vaskularisasi lancar yang membuat relaksasi pada otot menghilangkan ketegangan otot dan kekakuan sendi.

Hal yang paling utama yang menyebabkan dismenorea primer ada hubungannya dengan faktor endokrin yaitu hormon estrogen, progesterone dan prostaglandin. Saat satu hari menjelang ovulasi hormon estrogen akan turun, dan hormon progesteron akan meningkat. Teori tersebut berhubungan dengan pengaruh kompres hangat terhadap dismenorea primer, karena mekanisme terjadinya penurunan nyeri akibat dilakukan kompres hangat karena panas menyebabkan vasodilatasi. Selain itu ketika kompres diberikan juga akan merangsang serat saraf yang menutup gerbang karena adanya sensasi hangat sehingga transmisi implus nyeri ke medula spinalis dan otak dapat dihambat.

Sesuai yang disampaikan oleh (Potter \& Perry, 2006), panas juga merangsang serat saraf yang menutup gerbang sehingga transmisi implus nyeri ke medula spinalis dan otak dapat dihambat. Penurunan nyeri dengan transmisi yang dipengaruhi oleh teori gate control yaitu apabila terdapat impuls yang ditransmisikan oleh serabut berdiameter besar karena adanya stimulasi kulit, sentuhan, getaran, hangat dan dingin serta sentuhan halus, impuls ini akan menghambat impuls dari serabut berdiameter kecil di area SG (Substansia Gelatinosa) sehingga sensasi yang dibawa oleh serabut kecil akan berkurang atau bahkan tidak dihantarkan ke otak oleh SG, karenanya tubuh tidak dapat merasakan nyeri.

Menurut Potter dan Perry, (2006), mekanisme terjadinya penurunan nyeri akibat dilakukan kompres hangat karena ketika panas diterima reseptor, impuls akan diteruskan menuju hipotalamus posterior akan terjadi reaksi reflek penghambatan simpatis yang akan membuat pembuluh darah berdilatasi sehingga membantu meningkatkan aliran 
Murtiningsih: Penurunan Nyeri Dismenore Primer melalui Kompres Hangat

darah ke bagian perut bawah yang mengalami nyeri/dismenorea, panas meredakan nyeri dengan menyingkirkan produk-produk imflamasi seperti bradikinin, histamin dan prostaglandin yang menimbulkan rasa nyeri lokal.

\section{Simpulan}

Hasil penelitian didapatkan rata-rata skala nyeri dismenorea sebelum kompres 6.5, skala nyeri tertinggi 9 , terendah 4 dengan standard deviation 1.654. Sedangkan ratarata skala nyeri dismenorea setelah kompres hangat 4.22 , skala nyeri tertinggi 7 , terendah 1 dengan standard deviation 1.665. Hasil uji statistik didapatkan nilai $\mathrm{p}=0.000$, maka dapat disimpulkan pada $\alpha=0.05$ ada perbedaan yang signifikan antara skala nyeri dismenorea sebelum dengan sesudah kompres hangat, yang berarti terdapat pengaruh kompres hangat terhadap nyeri dismenorea primer pada remaja.

Berdasarkan hasil penelitian peneliti memberikan saran kepada pihak puskesmas dan sekolah agar rutin melakukan penyuluhan pada remaja putri yang mengalami dismenorea untuk mencoba menangani dismenorea tanpa menggunakan obat-obatan, tetapi menggunakan tehnik yang mudah, murah, efektif dan efesien yaitu kompres hangat yang terbukti dapat mengurangi nyeri dismenorea. Pihak sekolah terutama UKS diharapkan memfasilitasi peralatan untuk melakukan kompres hangat tersebut.

\section{Daftar Pustaka}

Ayu. (2010). Pengaruh Kompres Hangat Terhadap Dismenorea Primer Pada Mahasiswi semester VIII S1 Keperawatan di Universitas Muhammadiyah Semarang. Tersedia digilib.unimus.ac.id. (Diperoleh 20 Maret 2014).

Bajrai, A.A. et al. (2010). Gynaecological nursing. Shah Alam: Oxford University Press.

Barbara. R. (2003). Asisten Keperawatan Suatu Proses Pendekatan Keperawatan edisi ke-6. Jakarta: EGC.

Bobak. (2005). Keperawatan maternitas. Jakarta: EGC.

Dahlan. S. (2012). Langkah-langkah Membuat Proposal Penelitian Bidang Kedokteran Dan Kesehatan. Jakarta: Sagung Seto.

Guyton \& Hall. (2008). Buku Ajar Fisiologi Kedokteran. edisi ke-11. Jakarta: EGC.

Grove, S.K., Burn, N. \& Gray, J.R. (2013). The Practice of Nursing Research: Appraisal, Synthesis, and Generation of Evidence, $7^{\text {th }}$ edition. St.Louis Missouri: Elsevier Sounders.

Harry. (2006). Mekanisme Endhorphin Dalam Tubuh tersedia pada http//klikharry. files.wordpress.com. (Diperoleh 20 Maret 2014).

Kozier \& Erb's. (2009). Buku Ajar Praktik Keperawatan Klinis edisi ke-5. Jakarta: EGC.

Lowdermilk. (2010). Maternity nursing $8^{\text {th }}$ edition. Canada: Mosby.

Mahmudiono, T. (2011). Fiber, PUFA and Calcium Intake is Associated With The Degree of Primary Dysmenorrhea in Adolescent Girl Surabaya, Indonesia. Journal Obstetrics \& Gynecology.

Ningsih. (2011). Efektivitas Paket Pereda Terhadap Intensitas Nyeri Pada Remaja Dengan Dismenorea di SMAN Kecamatan Curup. Tersedia di http://lontar.ui.ac. id.(Diperoleh 19 maret 2014).

Oktaviana, A., \& Imron, R. (2012). Menurunkan Nyeri Dismenorea Dengan Kompres Hangat. Jurnal Keperawatan, 8 (2), 137-141.

Potter \& Perry. (2006). Buku Ajar Fundamental Keperawatan: Konsep, Proses dan Praktik edisi ke-1 volume ke-2. Jakarta: EGC.

Proverawati \& Misaroh. (2009). Menarch. 
Murtiningsih: Penurunan Nyeri Dismenore Primer melalui Kompres Hangat

Yogyakarta: Nuha Medika.

Sophia, F. (2013). Faktor-Faktor Yang Berhubungan Dengan Dismenorea Pada Siswi SMK Negeri 10 Medan tahun 2013. Tersedia pada http://jurnal/usu.ac.id. (Diperoleh 29 Maret 2014).

Tamsuri, A (2006). Konsep dan penatalaksanaan nyeri. Jakarta: EGC.

Wahyuningsih, A (2012). Efektifvtas kompres hangat dalam menurunkan intensitas nyeri dysmenorrhea pada mahasiswi stikes rs. baptis kediri. Tersedia pada http://repository. usu.ac.id/bitstream/123456789/16724/4/ Chapter\%20II.pdf (Diperoleh tanggal 21 januari 2014). 